Article

\title{
Rapid Synthesis of Gold Nanoparticles from Quercus incana and Their Antimicrobial Potential against Human Pathogens
}

\author{
Rizwana Sarwar ${ }^{1}$, Umar Farooq ${ }^{1, *}$, Muhammad Raza Shah ${ }^{2}$, Sara Khan ${ }^{1}$, Nadia Riaz ${ }^{3}$, \\ Sadia Naz ${ }^{1}$, Aliya Ibrar ${ }^{1}$ and Ajmal Khan ${ }^{1, *}$ \\ 1 Department of Chemistry, COMSATS Institute of Information Technology, Abbottabad 22060, Pakistan; \\ rizwanasarwar@ciit.net.pk (R.S.); zarrar92@live.com (S.K.); saadia_naaz@hotmail.com (S.N.); \\ aliya@ciit.net.pk (A.I.) \\ 2 Husein Ebrahim Jamal Research Institute of Chemistry, International Center for Chemical and Biological \\ Sciences, University of Karachi, Karachi 75270, Pakistan; raza.shah@iccs.edu \\ 3 Department of Environmental Sciences, COMSATS Institute of Information Technology, Abbottabad 22060, \\ Pakistan; nadiariazz@gmail.com \\ * Correspondence: umarf@ciit.net.pk (U.F.); ajmalkhan@ciit.net.pk (A.K.); Tel.: +92-334-933-2188 (A.K.) \\ Academic Editor: Raed Abu-Reziq \\ Received: 5 October 2016; Accepted: 9 December 2016; Published: 16 January 2017
}

\begin{abstract}
In current study, bioreduction of tetrachloroauric acid $\left(\mathrm{HAuCl}_{4} \cdot 3 \mathrm{H}_{2} \mathrm{O}\right)$ was carried out using leaves extract of Quercus incana for nanoparticle synthesis. The nanoparticles were characterized by ultraviolet visible spectrum (UV), Fourier-transform infrared (FT-IR), and transmission electron microscopy (TEM) analysis. The gold nanoparticles (GNPs) were generally clumpy agglomerates of polydispersed particles, with an average size in the range 5.5-10 $\mathrm{nm}$. The Gas chromatography-mass spectrometry (GC-MS) qualitative analysis and FT-IR data supported the presence of bioactive compounds, which are responsible for the metal reduction and nanoparticles stabilization. The biocompatibility of synthesized GNPs was evaluated via antibacterial activity by using human bacterial pathogens. The results showed that synthesized GNPs showed enhanced antibacterial activity against all bacterial pathogens.
\end{abstract}

Keywords: Quercus incana; nanoparticles; antibacterial activity; gold nanoparticles; GC-MS; transmission electron microscopy (TEM)

\section{Introduction}

Nanotechnology is predominantly concerned with synthesis of nanoparticles of variable sizes, shapes, and chemical compositions, along with their potential use in human welfare [1]. The metal and semiconductor nanoparticles synthesis is an extending research area for the potential applications of nanoparticles and for the advancement of novel technologies [2,3]. The nanoparticles can be synthesized by different methods (physical, chemical, and biological) and by using different substrates (pure compounds, microorganism, and plant extract) [4,5]. The chemical approach is robustly scaled for the large-scale production of nanoparticles of tunable shape and size by using different synthesis conditions. However, the chemical method uses toxic solvents, which are hazardous and makes them unsuitable for biomedical applications [6]. The physical methods for nanoparticles synthesis are expensive and not appropriate for large-scale production $[7,8]$. Therefore, there is an increasing demand to develop environmentally feasible, low-cost, energy-efficient, and high-yield procedures for their synthesis. So, the biological approaches (bacteria, fungi, yeasts, and plant/plant extract) for synthesizing nanoparticles become imperative to an ecofriendly synthesis procedure [9-11]. 
Silver as well as gold nanoparticles are of great medicinal importance. Gold nanoparticles (GNPs) possess unique physicochemical properties, which attract the interest and demand of nanoparticles researchers [12-14]. Gold nanoparticles find applications in sensor devices, catalysis, optoelectronics [15], and in medicine [16].

The unique and unexpected catalytic properties of GNPs [16,17] make them suitable for the small-sized nanoparticle synthesis $[15,18,19]$. GNPs have additionally been utilized for different applications, such as immunoassay [20,21], protein analysis assay [22], mass spectrometry [6], capillary electrophoresis [23], and identification of cancer cells [24]. Nanoparticles can act as antimicrobial agents, due to their ability to interact with microorganisms [25-27]. The interaction of nanoparticles with the cell wall of a microorganism disturbs the cell's functions by altering permeability, damaging the respiratory chain enzymes by depressing its activity, and, ultimately, causing cell death [28]. Plant-mediated nanoparticles have also been screened for antibacterial activity [29]. Silver nanoparticles are good antimicrobial agent and, in some studies, silver-based antimicrobial material was used to achieve a wide spectrum of functionalities [30]. Despite silver nanoparticles, gold nanoparticles were also screened for antibacterial potential. In one study, the author mixed gold nanoparticles with antibiotics, and enhancement in antibacterial activity was observed [31]. Another author's experimental finding showed that the observed activity was actually attributed to the antibiotic, not GNPs [32]. These results contradict the concept of the antibacterial activity possessed by GNPs. The present study, based on green chemistry synthesis of nanoparticles, proposes synthesis of nanoparticles using Quercus incana. The added advantage of using Quercus incana is that it simultaneously acts as a reducing, capping, and stabilizing agent. This study also compared the results of antimicrobial activities with standard and leaves extract of Quercus incana. To confirm the presence and support the synthesis of bioactive compounds, physiochemical, Gas chromatography-mass spectrometry (GC-MS) and Fourier-transform infrared (FT-IR) analyses were conducted.

\section{Materials and Methods}

\subsection{Preparation of Extract}

Leaves of Quercus incana (16 kg) were collected in May 2011, from District Abbottabad, Pakistan. The extraction and fractionation of plant material was reported in our previous study [33]. From the fraction of ethyl acetate, $500 \mathrm{mg}$ was dissolved in acetone (Sigma Aldrich, St. Louis, MO, USA) and marked up to $250 \mathrm{~mL}$.

\subsection{Synthesis of Nanoparticles}

One millimolar solution of tetrachloroauric acid $\left(\mathrm{HAuCl}_{4} \cdot 3 \mathrm{H}_{2} \mathrm{O}\right)(\mathrm{Sigma}$ Aldrich, St. Louis, MO, USA) was prepared in double-distilled water for the synthesis of GNPs. Different ratios of leaf extract and gold solution were set on a shaking bath for $4 \mathrm{~h}$ at room temperature to optimize the reaction. The mixture of leaf extract and gold solution was stirred thoroughly. After $15 \mathrm{~min}$, the reacting colorless solution changed to violet, indicating the synthesis of GNPs, which was later confirmed by UV-visible analysis.

\subsubsection{UV-Visible Spectrometric Analysis}

UV-visible spectra of colloidal gold solution were recorded as a function of wavelength on Thermo Scientific Evolution 300 UV-vis spectrophotometer (Shimadzu UV-240, Hitachi U-3200, Kyoto, Japan) in the range of $300-700 \mathrm{~nm}$, operated at the resolution of $1 \mathrm{~nm}$. Water and acetone mixture was used as reference solvent. 


\subsubsection{Transmission Electron Microscopy (TEM)}

The TEM analysis (Zeiss Libra transmission electron microscope, Carl Zeiss, Dublin, CA, USA) was performed to confirm the particle size and shape. For TEM examination, a small amount of synthesized GNPs was placed on a carbon-coated copper grid at an operating voltage of $120 \mathrm{KeV}$.

\subsubsection{Fourier-Transform Infrared Spectroscopy}

For FT-IR measurements, the GNP solution was centrifuged at 13,000 rpm for $30 \mathrm{~min}$. To remove the byproduct and free proteins/enzymes, the GNP solution was washed with deionized water. The IR spectra were recorded on an IR spectrophotometer (IR-460 Shimadzu, Kyoto, Japan) using translucent pellets of a GNP/KBr mixture (1:1).

\subsubsection{Identification of Compounds by GC-MS Analysis}

GC-MS analysis of the extract of Quercus incana was performed using a PerkinElmer GC Clarus 500 system (Waltham, MA, USA) Electron impact mode with ionization energy of $70 \mathrm{eV}$ was used for GC-MS detection. The carrier gas was helium (99.999\%) with a constant flow rate of $1 \mathrm{~mL} / \mathrm{min}$ and injection volume of $1 \mu \mathrm{L}$. The temperature settings of significance were the injector temperature $\left(250{ }^{\circ} \mathrm{C}\right)$, ion-source temperature $\left(200^{\circ} \mathrm{C}\right)$, and the oven temperature $\left(110-280^{\circ} \mathrm{C}\right)$.

Mass spectra of extract of Quercus incana were recorded at $70 \mathrm{eV}$, with a scan interval of $0.5 \mathrm{~s}$ and fragments from 45 to $450 \mathrm{Da}$. The total running time for GC-MS was about $36 \mathrm{~min}$ after temperature adjustment. The TurboMass Gold (PerkinElmer, Waltham, MA, USA) was used as a mass detector, and TurboMass version 5.2 (Perkin-Elmer, Waltham, MA, USA) was the software used for chromatograms in GC/MS analysis.

Library matching was performed by matching their mass spectra in National Institute of Standards and Technology Mass spectrometry (NIST MS) library, 2005.

\subsubsection{Antibacterial Potential of GNPs}

Antibacterial potential of synthesized GNPs was tested against clinically isolated bacterial pathogens. The Gram-negative pathogens included Salmonella setubal (ATCC 19196) and Pseudomonas pickettii (ATCC 49129), whereas Gram-positive pathogens included Bacillus subtilis (ATCC 6633) and Staphylococcus aureus (ATCC 6538). Antibacterial activity was determined by the agar-well diffusion method. The test cultures were swabbed on test media with sterile cotton swabs. A well of 6 mm diameter was made on a Muller Hinton agar plate using a sterile cork-borer (Sigma Aldrich, St. Louis, MO, USA). About $20 \mu \mathrm{L}$ of three concentrations $(25,50$, and $75 \mu \mathrm{g})$ of extract and GNPs were inoculated into the well. These plates were further incubated at $37^{\circ} \mathrm{C}$ for $24 \mathrm{~h}$. After the incubation period, the zones of inhibition were determined.

\subsubsection{Antifungal Potential of GNPs}

Antifungal potential of synthesized GNPs was explored using the agar-well diffusion method. Two fungal stains strains, Aspergillus flavus (ATCC 32611) and Aspergillus niger (ATCC 1015), were used for analyzing antifungal activity. Sabouraud dextrose agar plates were prepared and a $6 \mathrm{~mm}$ diameter well was made on the plate by gel puncture. The fungal cultures were swabbed with sterile cotton on test media, and $20 \mu \mathrm{L}$ of three concentrations $(25,50$, and $75 \mu \mathrm{g})$ of extract and synthesized GNPs were inoculated into the well. The test plates were incubated at $28^{\circ} \mathrm{C}$ (for $72 \mathrm{~h}$ ), then the zones of inhibition were analyzed. 


\section{Results and Discussion}

\subsection{Characterization of Gold Nanoparticles}

\section{UV-Visible Analysis}

In the UV-visible analysis, the interaction between the ethyl acetate fraction and metal ions was studied for their consistency in surface plasmon resonance properties and gold metal reduction rates by changing the extract ratios. In GNPs, gold ion reduction occurred rapidly within 15 min of the reaction onset, making it one of the fastest bioreducing methods [34,35]. A blue shift was observed from 5:1 to 7:1, which indicates a reduction in the diameter of gold nanoparticles. Reaction optimization occurred at 8:1 ratio of gold and leaf extract, as shown in Figure 1. Synthesized GNPs centered at $543 \mathrm{~nm}$ with a 2.84 absorption peak. The surface plasmon resonance greatly depends on the shape, size, and dielectric constant of the metal and the surrounding medium of GNPs [36]. The broad nature of surface plasmon absorption (SPR) peaks indicated the presence of polydispersed GNPs. When the ratio of gold solution was increased from 1 to 8 , while keeping the extract concentration constant, no shift in the SPR was observed (Figure 1), however the peak intensity increased, which was due to the development of more GNPs [37]. However, after the 8:1 ratio, a decrease in peak intensity occurred. After the 8:1 ratio of gold and salt, a decrease in absorption confirmed the decomposition of nanoparticles [38].

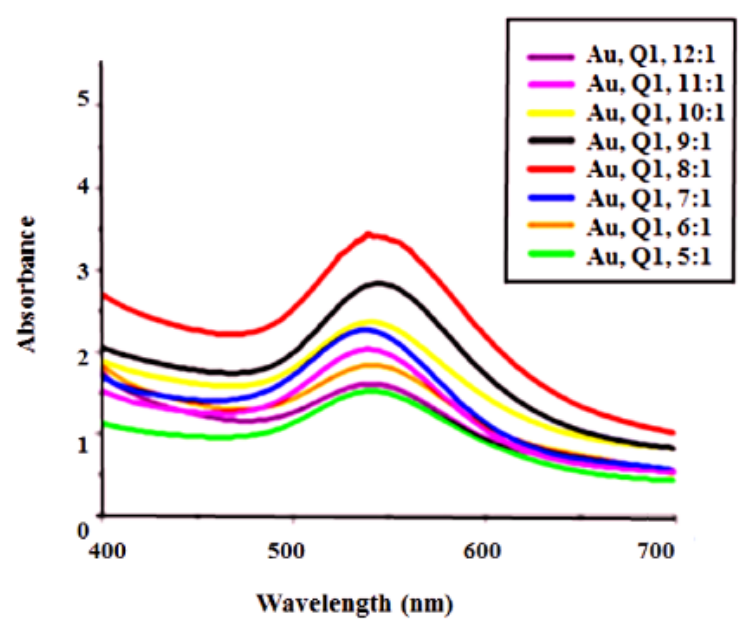

Figure 1. Optimization of GNPs.

\subsection{Stability of Gold Nanoparticles}

\subsubsection{Stability with the Time}

Although gold nanoparticles were synthesized within 15 min of the reaction, complete reduction of $\mathrm{Au}$ (III) to $\mathrm{Au}(0)$ required maximum $4 \mathrm{~h}$ as shown in Figure 2. The characteristic absorption peak for GNPs was found at the wavelength $\lambda_{\max }=543 \mathrm{~nm}$. This peak became more prominent with the passage of time via the complete reduction of gold metal. Over the $4 \mathrm{~h}$ reaction period, absorbance steadily increased until the complete reduction of gold metal by plant extract (Figure 2). They might have become stable after $4 \mathrm{~h}$, as no change in absorption occurred. The observed $\lambda_{\max }$ value was characteristic for the surface plasmon resonance peak of GNPs, which was due to the collective oscillation of free conduction electrons of GNPs in resonance induced by the interacting electromagnetic field [37,39]. 


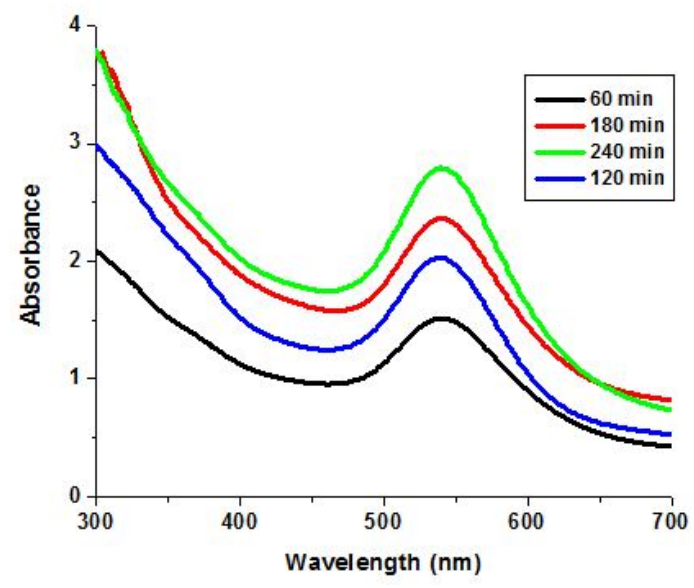

Figure 2. Change in absorption with the passage of time.

\subsubsection{Heat Stability}

Heat stability of GNPs was also studied using a high-temperature range. For this purpose, GNPs were heated to $80^{\circ} \mathrm{C}$ for $30 \mathrm{~min}$, and the stability was checked by comparing absorption before and after heating. Nanoparticles showed thermal stability (Figure 3), but increase in absorption was observed after heating. The notable difference in UV-vis spectra for the synthesized GNPs was a change in the height of the peaks (which may relate to the number of the nanoparticles produced, as the optical density (OD) value correlates linearly with the concentration of the gold nanoparticles) [40]. The increase in absorption was due to their uniform distribution in size and small size [41].

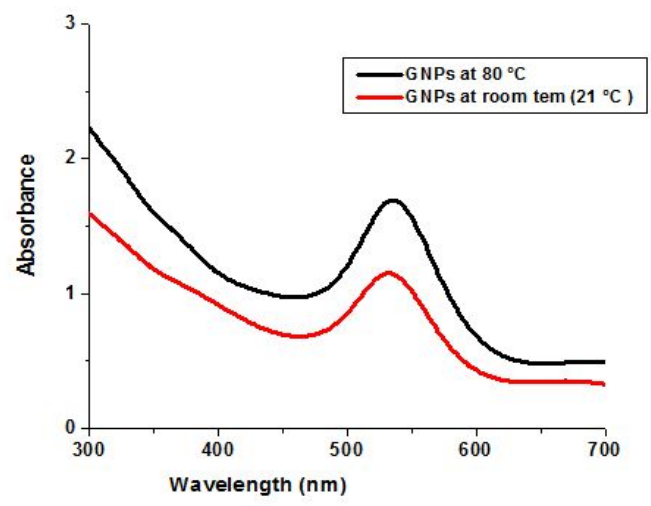

Figure 3. Effect of heat on GNPs.

\subsection{3. pH Stability of GNPs}

$\mathrm{pH}$ plays an important role in controlling nanoparticle size by affecting the surface charge stability and particle interaction. A digital pH meter (model 510, Oakton, Eutech, Vernon Hills, IL, USA) was used for the $\mathrm{pH}$ measurements of gold nanoparticles. To check the $\mathrm{pH}$ effect, acidic $(\mathrm{HCl})$ and alkaline $(\mathrm{NaOH})$ solutions were prepared and added to nanoparticles solution. This solution was kept for 2 days, and their stability was checked by observing absorption on a UV-visible spectrophotometer. The cleared solution and UV results supported the stability of nanoparticles at all $\mathrm{pH}$ values (Figure 4). 


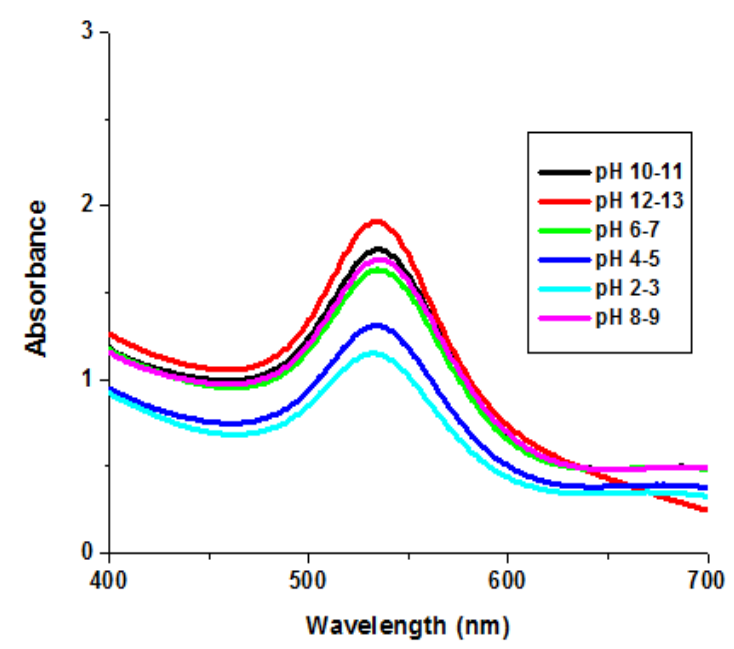

Figure 4. Effect of $\mathrm{pH}$ on GNPs.

\subsection{Spectroscopy (FT-IR)}

A representative FT-IR spectrum of the synthesized nanoparticles and extract is shown in Figure 5. The leaves extract showed prominent peaks at 1074, 1723, 2927, and $3413 \mathrm{~cm}^{-1}$.

In ethyl acetate extract, $\mathrm{O}-\mathrm{H}$ and aldehydic $\mathrm{C}-\mathrm{H}$ stretching was observed at 3413 and $2927 \mathrm{~cm}^{-1}$. For amide I, one absorption band was observed at $1635 \mathrm{~cm}^{-1}$, whereas the $\alpha, \beta$ unsaturated aldehydes group showed an absorption band at $1709 \mathrm{~cm}^{-1}$.

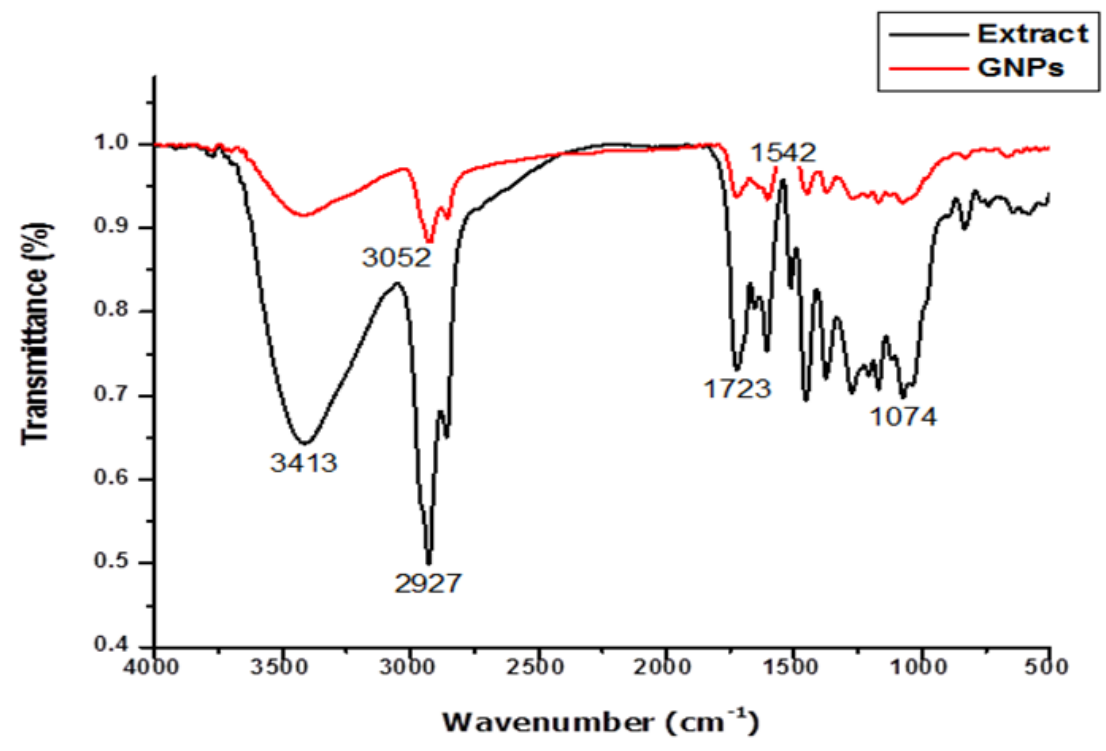

Figure 5. FTIR spectrum of extract and GNPs.

The $\mathrm{C}-\mathrm{N}$ stretching vibration of the amine group was observed at $1074 \mathrm{~cm}^{-1}$. The carbonyl group of amino acid and protein showed correlation with metal and showed ability to bind at the active site to prevent agglomeration, thus stabilizing the nanoparticles. The bioactive constituents in the ethyl acetate fraction could possibly perform dual functions for gold nanoparticles, namely, their (1) synthesis and (2) stabilization. The adsorption band for aromatic groups $(C=C)$, germinal methyls, and aromatic $C-C$ for gold nanoparticles were observed at 1618, 1452, and $1056 \mathrm{~cm}^{-1}$, respectively. The FT-IR spectra of Spirulina platensis showed gold ion peaks at 1242, 1541, and $1653 \mathrm{~cm}^{-1}$ [9]. 


\subsection{Transmission Electron Microscopy (TEM)}

The TEM examination of the GNPs confirmed that the synthesized GNPs were clumpy agglomerates that were polydispersed (Figure 6). After careful observation of the TEM image, it was found that the GNPs were prepared with an amazing size range of 5-12 nm.

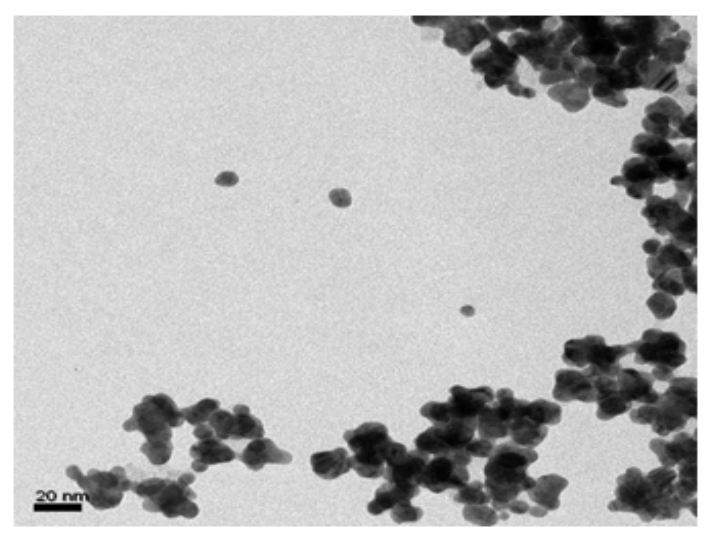

Figure 6. TEM image of GNPs.

\subsection{GC-MS Analysis of Ethyl Acetate Extract of Quercus incana}

GC-MS spectrum of ethyl acetate extract of Quercus incana showed sharper and broad peaks after 18 min of retention time (Figure 7). These peaks were searched in NIST library (ADMIS 2005), but most of them did not produce matching results of good quality. Few compounds were identified by comparing the extract mass spectra with the NIST library (Table 1)

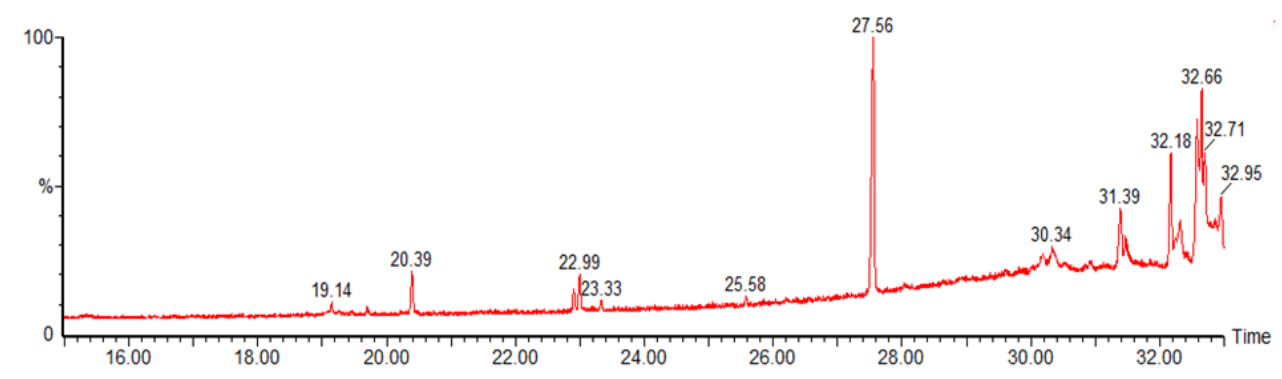

Figure 7. GC-MS spectrum of ethyl acetate extract of Quercus incana.

Table 1. Compounds list by matching NIST library.

\begin{tabular}{cccccc}
\hline S No. & Rt (min) & Compound & Molecular Formula & Molecular Weight & NIST ID \\
\hline 1 & 20.39 & Cyclopentyl carboxylic acid & $\mathrm{C}_{6} \mathrm{H}_{10} \mathrm{O}_{2}$ & 114 & 3217 \\
2 & 22.99 & 3-Dimethylaminocrylonitrile & $\mathrm{C}_{5} \mathrm{H}_{8} \mathrm{~N}_{2}$ & 96 & 53,996 \\
3 & 25.56 & 4-AminoFurazan-3-carbhydroamic acid & $\mathrm{C}_{3} \mathrm{H}_{5} \mathrm{O}_{2} \mathrm{~N}_{5}$ & 143 & 262,446 \\
4 & 27.56 & Dibutyl phthalate & $\mathrm{C}_{16} \mathrm{H}_{22} \mathrm{O}_{4}$ & 278 & 228,847 \\
5 & 30.34 & 3,5-Dimethyldihydropyran-2,6-dione & $\mathrm{C}_{7} \mathrm{H}_{16} \mathrm{O}_{3}$ & 142 & 18,795 \\
6 & 31.39 & 7,11-Hexadecadien-1-ol, acetate, & $\mathrm{C}_{18} \mathrm{H}_{32} \mathrm{O}_{2}$ & 280 & 130,865 \\
7 & 32.18 & Quinoline, decahydro cis & $\mathrm{C}_{9} \mathrm{H}_{17} \mathrm{~N}$ & 139 & 54,094 \\
8 & 32.66 & (1-Methoxy-pentyl)-cyclopropane & $\mathrm{C}_{9} \mathrm{H}_{18} \mathrm{O}$ & 142 & 46,868 \\
\hline
\end{tabular}

In current study compound 4 showed retention time of 27.56 which is in agreement with literature [42] A broad and prominent peak was observed in the spectrum. The mass spectrum of compound 4 is given below (Figure 8). This was compared with the mass spectrum of dibutyl phthalate, and the maximum peaks of dibutyl phthalate matched with compound 4 . Compound 7 was 
found at 32.18 min retention time (Figure 9), which was also reported for Tecomella undulate [43] with an amount of $17.13 \%$, while in present study, the compound was observed to be $32.18 \%$ by area. This compound belonged to an alkaloid class of compounds and also reported for Haliclona tulearensis [44]. Compounds 2 and 3 might be responsible for the reduction and stabilization of nanoparticles. It is supposed that different-shaped polyol and water-soluble heterocyclic plant constituents are mainly responsible for the reduction of gold ions.
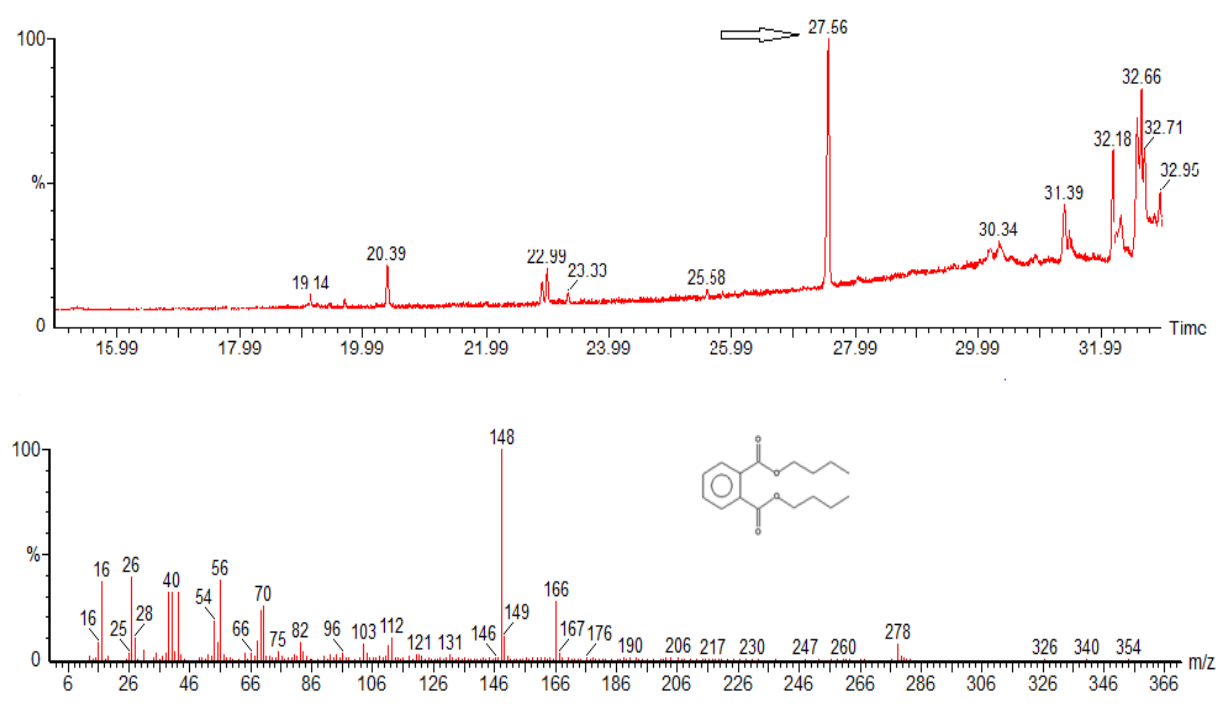

Figure 8. GC-MS of compound 4.
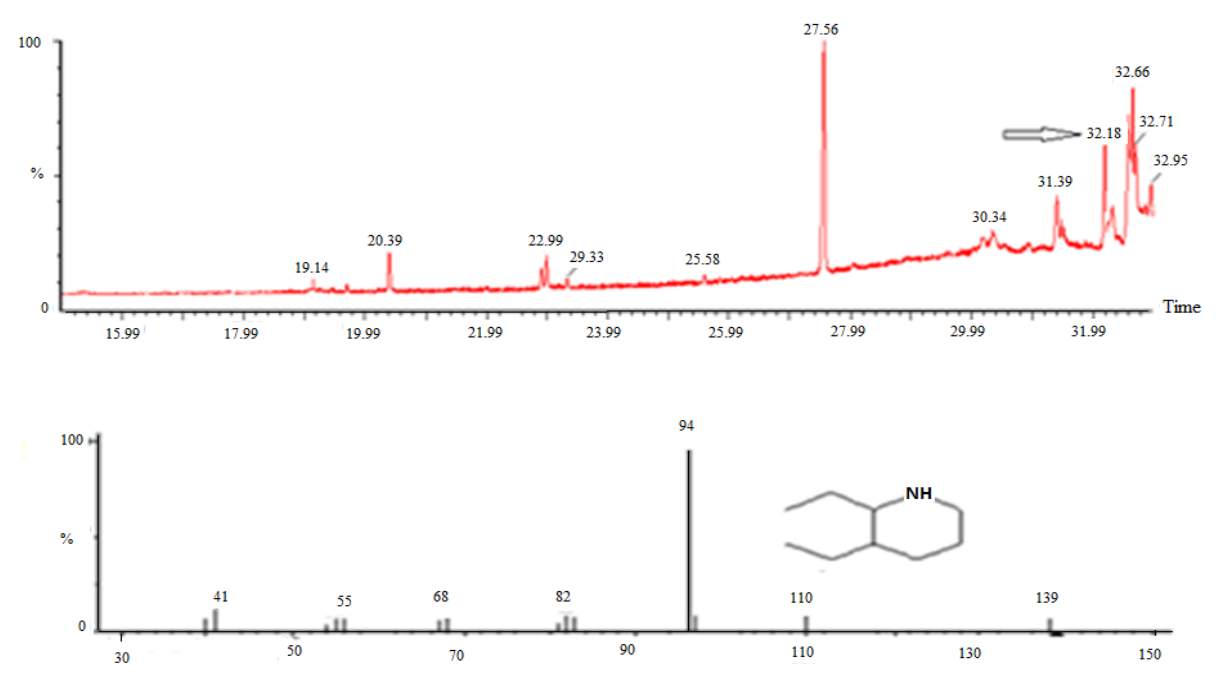

Figure 9. GC-MS of compound 7.

\subsection{Qualitative Analysis}

The qualitative analysis is very essential for identifying the compounds present in the plant. Green synthesis of nanoparticles takes place in the absence of reducing agents, which indicates that plants may contain bioactive compounds that act as reducing as well as capping agents.

These bioactive compounds are not only responsible for the nanoparticles synthesis, but also act as capping agents to prevent the coalescence of colloidal particles, which are kept apart in solution by electrostatic forces. It is supposed that different-shaped polyol and water-soluble heterocyclic plant constituents are mainly responsible for the reduction of gold ions [45]. Result of ethyl acetate fraction of Quercus incana showed tested positive for the bioactive compounds (Table 2). 
Table 2. Phytochemical analysis of Quercus incana.

\begin{tabular}{cccc}
\hline Phytochemical & Result & Method & References \\
\hline Alkaloids & + & Mayer's test & {$[46]$} \\
Carbohydrates & + & Molish's test & {$[46]$} \\
Glycoside & + & Bortrager test & {$[46]$} \\
Proteins and amino acids & + & Biuret test, Ninhydrin test & {$[47]$} \\
Flavonoids & + & Alkaline reagent test & {$[47]$} \\
Phenolic compounds & + & Lead acetate test & {$[47]$} \\
\hline
\end{tabular}

\subsection{Antibacterial Activity}

Phytochemical constituents present in plants, serve as a defensive tool against microorganisms, insects, and herbivores [48,49]. The demonstration of antibacterial activity against bacterial strains may indicate the presence of antibiotic compounds. For antibacterial activity, there might be two of these mechanisms. Firstly, due to reduced adenosine triphosphate (ATP) synthase activities, GNPs might have changed the membrane potential. In the second mechanism, GNPs might have collapsed the biological mechanism by decreasing levels of subunit of the ribosome for tRNA [28]. Synthesized gold nanoparticles showed effective antibacterial activity against the test pathogens as compared to ethyl acetate extract of Quercus incana. Nanoparticles showed inhibition at the concentration where ethyl acetate was unable to inhibit test pathogens. GNPs were most effective against Bacillus subtilis and Salmonella setubal, where they showed 9 and $7 \mathrm{~mm}$ zones of inhibition at the concentration of $75 \mu \mathrm{g}$ (Table 3). They were least active against Pseudomonas pickettii and S. aureus, showing 3 and $6 \mathrm{~mm}$ zones of inhibition at the concentration of $75 \mu \mathrm{g}$, but inactive at $25 \mu \mathrm{g}$. Here, it was also found that with an increase in the concentration of GNPs, the zones of inhibition also increased, even exceeding the antibiotic's zone of inhibition.

Table 3. Antibacterial assay of extract and gold nanoparticles (GNPs).

\begin{tabular}{|c|c|c|c|c|c|c|c|c|c|}
\hline \multirow{2}{*}{$\begin{array}{l}\text { Bacterial } \\
\text { Isolate }\end{array}$} & \multicolumn{4}{|c|}{ GNPs Zone of Inhibition (mm) } & \multicolumn{4}{|c|}{ Plant extract Zone of Inhibition (mm) } & \multirow{2}{*}{$\begin{array}{c}\text { Ciprofloxacin } \\
5 \mu \mathrm{g} / \mathrm{mL}\end{array}$} \\
\hline & $25 \mu \mathrm{g}$ & $50 \mu \mathrm{g}$ & $75 \mu \mathrm{g}$ & $1 \mathrm{mg}$ & $25 \mu \mathrm{g}$ & $50 \mu \mathrm{g}$ & $75 \mu \mathrm{g}$ & $1 \mathrm{mg}$ & \\
\hline B. subtilis & 6 & 8 & 9 & 17 & 0 & 0 & 0 & 8 & 13 \\
\hline S. aureus & 0 & 4 & 6 & 12 & 0 & 0 & 0 & 11 & 22 \\
\hline S. setubal & 3 & 5 & 7 & 15 & 0 & 0 & 0 & 8 & 24 \\
\hline P. pickettii & 0 & 0 & 3 & 9 & 0 & 0 & 0 & 0 & 20 \\
\hline
\end{tabular}

\subsection{Antifungal Activity}

Synthesized gold nanoparticles showed moderate antifungal activity against the test pathogens Aspergillus flavus and Aspergillus niger by comparing it with crude extract (inactive in microgram concentrations while active in milligram concentration). Gold nanoparticles were found to be more active against Aspergillus niger. In another study, when the antimicrobial potential of GNPs was determined by mixing gold nanoparticles with antibiotic, enhanced antimicrobial potency of GNPs was observed [50]. In our study, it was found that gold nanoparticles showed moderate activity as compared to the plant extract (Table 4).

Table 4. Antifungal assay of extract and GNPs.

\begin{tabular}{|c|c|c|c|c|c|c|c|c|c|}
\hline \multirow{2}{*}{ Fungal Strain } & \multicolumn{4}{|c|}{ GNPs Zone of Inhibition (mm) } & \multicolumn{4}{|c|}{ Plant extract Zone of Inhibition (mm) } & \multirow{2}{*}{$\begin{array}{l}\text { Nystatin } \\
5 \mu \mathrm{g} / \mathrm{mL}\end{array}$} \\
\hline & $25 \mu \mathrm{g}$ & $50 \mu \mathrm{g}$ & $75 \mu \mathrm{g}$ & $1 \mathrm{mg}$ & $25 \mu \mathrm{g}$ & $50 \mu \mathrm{g}$ & $75 \mu \mathrm{g}$ & $1 \mathrm{mg}$ & \\
\hline Aspergillus flavus & 0 & 0 & 5 & 9 & 0 & 0 & 0 & 4 & 11 \\
\hline Aspergillus niger & 0 & 3 & 5 & 7 & 0 & 0 & 0 & 6 & 17 \\
\hline
\end{tabular}




\section{Conclusions}

This is the first report on the green synthesis of GNPs using ethyl acetate extract of Quercus incana. GNP synthesis was confirmed by UV-visible spectra, IR spectra, and by TEM analysis. GNPs showed a strong broad absorption peak at $543 \mathrm{~nm}$. The synthesized nanoparticles were clumpy agglomerates of polydispersed particles with an average size of $5-15 \mathrm{~nm}$. The antimicrobial efficacy of the nanoparticles depends on the shape and concentration of the nanoparticles. This can be confirmed by studying the inhibition of bacterial growth by differentially shaped nanoparticles [51]. Nanoparticles have large surface area available for interactions, which enhances bactericidal effect compared to the large-sized particles; hence, they impart cytotoxicity to the microorganism [52]. Quercus incana appears to have significant antimicrobial capacity resembling a broad spectrum antibiotic against the human pathogenic Pseudomonas pickettii, Salmonella setubal, Staphylococcus aureus, Bacillus subtilis, Aspergillus flavus, and Aspergillus niger.

Acknowledgments: The author is grateful to International Center for Chemical and Biological Sciences, Hussain Ebrahim Jamal Research Institute of Chemistry, University of Karachi, Higher Education Commission (HEC) Pakistan and COMSATS Institute of information technology, Pakistan for providing financial support for this work.

Author Contributions: Umar Farooq and Ajmal Khan conceived and designed the experiments. Rizwana Sarwar performed the experiments; Muhammad Raza Shah analyzed the data; Sara Khan and Sadia Naz carried out biological activities; Aliya Ibrar and Nadia Riaz were involved in writing, editing of manuscript. All authors have read and approved the final version of the manuscript.

Conflicts of Interest: The authors declare no conflict of interest.

\section{Abbreviations}

The following abbreviations are used in this manuscript:

$\begin{array}{ll}\text { GNPs } & \text { Gold Nanoparticles } \\ \text { TEM } & \text { Transmission Electron Microscopy } \\ \text { FT-IR } & \text { Fourier Transform Infrared Spectroscopy } \\ \text { SPR } & \text { Surface Plasmon Resonance }\end{array}$

\section{References}

1. Sujatha, S.; Tamilselvi, S.; Subha, K.; Panneerselvam, A. Studies on biosynthesis of silver nanoparticles using Mushroom and its antibacterial activities. Int. J. Curr. Microbiol. Appl. Sci. 2013, 2, 605-614.

2. Pandiyarajan, T.; Udayabhaskar, R.; Vignesh, S.; James, R.A.; Karthikeyan, B. Synthesis and concentration dependent antibacterial activities of CuO nanoflakes. Mater. Sci. Eng. C 2013, 33, 2020-2024. [CrossRef] [PubMed]

3. Surya, M. Biocompatible synthesis of silver nanoparticles (AgNPs) using marine Vibrio sp. and study their pharmacological applications. Int. J. Phytopharm. 2015, 5, 65-71.

4. Kundu, S.; Wang, K.; Liang, H. Size-controlled synthesis and self-assembly of silver nanoparticles within a minute using microwave irradiation. J. Phys. Chem. C 2008, 113, 134-141. [CrossRef]

5. Tsuji, M.; Hashimoto, M.; Nishizawa, Y.; Tsuji, T. Preparation of gold nanoplates by a microwave-polyol method. Chem. Lett. 2003, 32, 1114-1115. [CrossRef]

6. Kim, Y.-P.; Oh, E.; Hong, M.-Y.; Lee, D.; Han, M.-K.; Shon, H.K.; Moon, D.W.; Kim, H.-S.; Lee, T.G. Gold nanoparticle-enhanced secondary ion mass spectrometry imaging of peptides on self-assembled monolayers. Anal. Chem. 2006, 78, 1913-1920. [CrossRef] [PubMed]

7. Narayanan, S.; Sathy, B.N.; Mony, U.; Koyakutty, M.; Nair, S.V.; Menon, D. Biocompatible magnetite/gold nanohybrid contrast agents via green chemistry for MRI and CT bioimaging. ACS Appl. Mater. Interfaces 2011, 4, 251-260. [CrossRef] [PubMed]

8. Raveendran, P.; Fu, J.; Wallen, S.L. Completely “green" synthesis and stabilization of metal nanoparticles. J. Am. Chem. Soc. 2003, 125, 13940-13941. [CrossRef] [PubMed]

9. Govindaraju, K.; Basha, S.K.; Kumar, V.G.; Singaravelu, G. Silver, gold and bimetallic nanoparticles production using single-cell protein (Spirulina platensis) Geitler. J. Mater. Sci. 2008, 43, 5115-5122. [CrossRef] 
10. Kowshik, M.; Deshmukh, N.; Vogel, W.; Urban, J.; Kulkarni, S.K.; Paknikar, K. Microbial synthesis of semiconductor CdS nanoparticles, their characterization, and their use in the fabrication of an ideal diode. Biotechnol. Bioeng. 2002, 78, 583-588. [CrossRef] [PubMed]

11. Lengke, M.F.; Fleet, M.E.; Southam, G. Biosynthesis of silver nanoparticles by filamentous cyanobacteria from a silver (I) nitrate complex. Langmuir 2007, 23, 2694-2699. [CrossRef] [PubMed]

12. Daniel, M.-C.; Astruc, D. Gold nanoparticles: Assembly, supramolecular chemistry, quantum-size-related properties, and applications toward biology, catalysis, and nanotechnology. Chem. Rev. 2004, 104, 293-346. [CrossRef] [PubMed]

13. Laguna, A. Modern Supramolecular Gold Chemistry: Gold-Metal Interactions and Applications; John Wiley \& Sons: Hoboken, NJ, USA, 2008.

14. Zhou, J.; Ralston, J.; Sedev, R.; Beattie, D.A. Functionalized gold nanoparticles: Synthesis, structure and colloid stability. J. Colloid Interface Sci. 2009, 331, 251-262. [CrossRef] [PubMed]

15. Shipway, A.N.; Katz, E.; Willner, I. Nanoparticle arrays on surfaces for electronic, optical, and sensor applications. ChemPhysChem 2000, 1, 18-52. [CrossRef]

16. Han, G.; Ghosh, P.; Rotello, V.M. Functionalized gold nanoparticles for drug delivery. Nanomedicine (Lond.) 2007, 2, 113-123. [CrossRef] [PubMed]

17. Hashmi, A.S.K.; Hutchings, G.J. Gold catalysis. Angew. Chem. Int. Ed. 2006, 45, 7896-7936. [CrossRef] [PubMed]

18. Quinet, E.; Piccolo, L.; Morfin, F.; Avenier, P.; Diehl, F.; Caps, V.; Rousset, J.-L. On the mechanism of hydrogen-promoted gold-catalyzed CO oxidation. J. Catal. 2009, 268, 384-389. [CrossRef]

19. Turner, M.; Golovko, V.B.; Vaughan, O.P.; Abdulkin, P.; Berenguer-Murcia, A.; Tikhov, M.S.; Johnson, B.F.; Lambert, R.M. Selective oxidation with dioxygen by gold nanoparticle catalysts derived from 55-atom clusters. Nature 2008, 454, 981-983. [CrossRef] [PubMed]

20. Hirsh, L.; Stafford, R.; Bankson, J.; Sershen, S.; Rivera, B.; Price, R.; Hazle, J.; Halas, N.; West, J. Nanoshell-mediated near-infrared thermal therapy of tumors under magnetic resonance guidance. Proc. Natl. Acad. Sci. USA 2003, 100, 13549-13554. [CrossRef] [PubMed]

21. Liu, X.; Dai, Q.; Austin, L.; Coutts, J.; Knowles, G.; Zou, J.; Chen, H.; Huo, Q. A one-step homogeneous immunoassay for cancer biomarker detection using gold nanoparticle probes coupled with dynamic light scattering. J. Am. Chem. Soc. 2008, 130, 2780-2782. [CrossRef] [PubMed]

22. Tang, D.; Yuan, R.; Chai, Y. Biochemical and immunochemical characterization of the antigen-antibody reaction on a non-toxic biomimetic interface immobilized red blood cells of crucian carp and gold nanoparticles. Biosens. Bioelectron. 2007, 22, 1116-1120. [CrossRef] [PubMed]

23. Tseng, W.L.; Huang, M.F.; Huang, Y.F.; Chang, H.T. Nanoparticle-filled capillary electrophoresis for the separation of long DNA molecules in the presence of hydrodynamic and electrokinetic forces. Electrophoresis 2005, 26, 3069-3075. [CrossRef] [PubMed]

24. Kah, J.C.Y.; Kho, K.W.; Lee, C.G.L.; Richard, C.J. Early diagnosis of oral cancer based on the surface plasmon resonance of gold nanoparticles. Int. J. Nanomed. 2007, 2, 785-789.

25. Dror-Ehre, A.; Mamane, H.; Belenkova, T.; Markovich, G.; Adin, A. Silver nanoparticle-E. coli colloidal interaction in water and effect on E. coli survival. J. Colloid Interface Sci. 2009, 339, 521-526. [CrossRef] [PubMed]

26. Eby, D.M.; Schaeublin, N.M.; Farrington, K.E.; Hussain, S.M.; Johnson, G.R. Lysozyme catalyzes the formation of antimicrobial silver nanoparticles. ACS Nano 2009, 3, 984-994. [CrossRef] [PubMed]

27. Hernández-Sierra, J.F.; Ruiz, F.; Pena, D.C.C.; Martínez-Gutiérrez, F.; Martínez, A.E.; Guillén, A.D.J.P.; Tapia-Pérez, H.; Castañón, G.M. The antimicrobial sensitivity of Streptococcus mutans to nanoparticles of silver, zinc oxide, and gold. Nanomedicine 2008, 4, 237-240. [CrossRef] [PubMed]

28. Cui, Y.; Zhao, Y.; Tian, Y.; Zhang, W.; Lü, X.; Jiang, X. The molecular mechanism of action of bactericidal gold nanoparticles on Escherichia coli. Biomaterials 2012, 33, 2327-2333. [CrossRef] [PubMed]

29. Li, W.-R.; Xie, X.-B.; Shi, Q.-S.; Zeng, H.-Y.; You-Sheng, O.-Y.; Chen, Y.-B. Antibacterial activity and mechanism of silver nanoparticles on Escherichia coli. Appl. Microbiol. Biotechnol. 2010, 85, 1115-1122. [CrossRef] [PubMed]

30. Zhang, M.; Zhao, Y.; Yan, L.; Peltier, R.; Hui, W.; Yao, X.; Cui, Y.; Chen, X.; Sun, H.; Wang, Z. Interfacial Engineering of Bimetallic Ag/Pt Nanoparticles on Reduced Graphene Oxide Matrix for Enhanced Antimicrobial Activity. ACS Appl. Mater. Interfaces 2016, 8, 8834-8840. [CrossRef] [PubMed] 
31. Grace, A.N.; Pandian, K. Antibacterial efficacy of aminoglycosidic antibiotics protected gold nanoparticles-A brief study. Colloids Surfaces A 2007, 297, 63-70. [CrossRef]

32. Burygin, G.; Khlebtsov, B.; Shantrokha, A.; Dykman, L.; Bogatyrev, V.; Khlebtsov, N. On the enhanced antibacterial activity of antibiotics mixed with gold nanoparticles. Nanoscale Res. Lett. 2009, 4, $794-801$. [CrossRef] [PubMed]

33. Sarwar, R.; Farooq, U.; Khan, A.; Naz, S.; Khan, S.; Khan, A.; Rauf, A.; Bahadar, H.; Uddin, R. Evaluation of Antioxidant, Free Radical Scavenging, and Antimicrobial Activity of Quercus incana Roxb. Front. Pharmacol. 2015, 6, 277. [CrossRef] [PubMed]

34. Basavegowda, N.; Sobczak-Kupiec, A.; Malina, D.; Yathirajan, H.; Keerthi, V.; Chandrashekar, N.; Dinkar, S.; Liny, P. Plant mediated synthesis of gold nanoparticles using fruit extracts of Ananas comosus (L.)(Pineapple) and evaluation of biological activities. Adv. Mater. Lett. 2013, 4, 332-337. [CrossRef]

35. Begum, N.A.; Mondal, S.; Basu, S.; Laskar, R.A.; Mandal, D. Biogenic synthesis of Au and Ag nanoparticles using aqueous solutions of Black Tea leaf extracts. Colloids Surfaces B Biointerfaces 2009, 71, 113-118. [CrossRef] [PubMed]

36. Song, J.Y.; Jang, H.-K.; Kim, B.S. Biological synthesis of gold nanoparticles using Magnolia kobus and Diopyros kaki leaf extracts. Process Biochem. 2009, 44, 1133-1138. [CrossRef]

37. Huang, H.; Yang, X. Synthesis of polysaccharide-stabilized gold and silver nanoparticles: A green method. Carbohydr. Res. 2004, 339, 2627-2631. [CrossRef] [PubMed]

38. Khalil, M.M.; Ismail, E.H.; El-Baghdady, K.Z.; Mohamed, D. Green synthesis of silver nanoparticles using olive leaf extract and its antibacterial activity. Arabian J. Chem. 2014, 7, 1131-1139. [CrossRef]

39. Toderas, F.; Iosin, M.; Astilean, S. Luminescence properties of gold nanorods. Nuclear Instrum. Methods Phys. Res. Sect. B 2009, 267, 400-402. [CrossRef]

40. Abdelhalim, M.A.K.; Mady, M.M.; Ghannam, M.M. Physical properties of different gold nanoparticles: Ultraviolet-visible and fluorescence measurements. J. Nanomed. Nanotechnol. 2012, 3, 133. [CrossRef]

41. Pandey, S.; Oza, G.; Mewada, A.; Sharon, M. Green synthesis of highly stable gold nanoparticles using Momordica charantia as nano fabricator. Arch. Appl. Sci. Res. 2012, 4, 1135-1141.

42. Vimalavady, A.; Kadavul, K. Phytocomponents identified on the various extracts of stem of Hugonia mystax L.(Linaceae). Eur. J. Exp. Biol. 2013, 3, 73-80.

43. Laghari, A.Q.; Memon, S.; Nelofar, A.; Laghari, A.H. Structurally diverse alkaloids from Tecomella undulata G. Don flowers. J. King Saud Univ. Sci. 2014, 26, 300-304. [CrossRef]

44. Jones, T.H.; Gorman, J.S.; Snelling, R.R.; Delabie, J.H.; Blum, M.S.; Garraffo, H.M.; Jain, P.; Daly, J.W.; Spande, T.F. Further alkaloids common to ants and frogs: Decahydroquinolines and a quinolizidine. J. Chem. Ecol. 1999, 25, 1179-1193. [CrossRef]

45. Kumar, V.; Yadav, S.K. Plant-mediated synthesis of silver and gold nanoparticles and their applications. J. Chem. Technol. Biotechnol. 2009, 84, 151-157. [CrossRef]

46. William, E.C. Trease and Evans Pharmacology; Harcourt Brace and company. Asia. Pvt. Ltd.: Singapore, 1997.

47. Harborne, J.B. Phytochemical Methods a Guide to Modern Techniques of Plant Analysis; Springer Science \& Business Media: Berlin, Germany, 1998.

48. Chitravadivu, C.; Manian, S.; Kalaichelvi, K. Qualitative analysis of selected medicinal plants, Tamilnadu, India. Middle East J. Sci. Res. 2009, 4, 144-146.

49. Jamil, M.; Ul Haq, I.; Mirza, B.; Qayyum, M. Isolation of antibacterial compounds from Quercus dilatata L. through bioassay guided fractionation. Ann. Clin. Microbiol. Antimicrob. 2012, 11, 11. [CrossRef] [PubMed]

50. Nagaraj, B.; Malakar, B.; Divya, T.; Krishnamurthy, N.; Liny, P.; Dinesh, R.; Iconaru, S.; Ciobanu, C. Synthesis of plant mediated gold nanoparticles using flower extracts of Carthamus tinctorius L. (safflower) and evaluation of their biological activities. Dig. J. Nanomater. Biostruct. 2012, 7, 1289-1296.

51. Lutterodt, G.; Ismail, A.; Basheer, R.; Baharudin, H.M. Antimicrobial effects of Psidium guajava extract as one mechanism of its antidiarrhoeal action. Malays. J. Med. Sci. 1999, 6, 17-20. [PubMed]

52. Cowan, M.M. Plant products as antimicrobial agents. Clin. Microbiol. Rev. 1999, 12, 564-582. [PubMed]

(C) 2017 by the authors; licensee MDPI, Basel, Switzerland. This article is an open access article distributed under the terms and conditions of the Creative Commons Attribution (CC-BY) license (http:/ / creativecommons.org/licenses/by/4.0/). 